\title{
FÜSTÖLT BARRAMUNDI FILÉ TERMÉKEK HAZAI FOGYASZTÓI MEGÍTÉLÉSÉNEK VIZSGÁLATA
}

\author{
- भी० - \\ TESTING FOR CONSUMER PREFERENCES OF
SMOKED ASIAN SEA BASS (BARRAMUNDI) FILET PRODUCTS IN HUNGARY
}

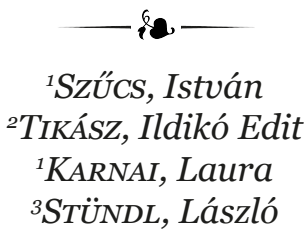

$+2$

\author{
Debreceni Egyetem, Gazdaságtudományi Kar, Gazdálkodástudományi Intézet \\ (University of Debrecen, Faculty of Economics and Business, Institute of Applied Economics Sciences) \\ H-4032 Debrecen, Böszörményi út. 138. \\ e-mail: szucs.istvan@econ.unideb.hu \\ ${ }^{2}$ Agrárgazdasági Kutató Intézet \\ (Research Institute of Agricultural Economics) \\ H-1093 Budatest IX. kerület, Zsil utca 3-5. \\ ${ }^{3}$ Debreceni Egyetem, Mezőgazdaság-, Élelmiszertudományi és Környezetgazdálkodási Kar, Állattudományi, \\ Biotechnológiai és Természetvédelmi Intézet \\ (University of Debrecen, Faculty of the Agricultural and Food Sciences and Environmental Management, \\ Institute of Animal Sciences, Biotechnology and Nature Conservation) \\ H-4032 Debrecen, Böszörményi út. 138.
}

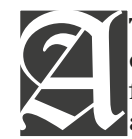

The present paper discusses the findings of primary research studies related to the development of smoked fish fillet made of the barramundi fish species into a functional food, connected to product tasting. The study sought to provide information for the target audience, in our case, for consumers in hypermarkets on (1) their certain fish consumption habits, (2) their attitudes towards conscious fish consumption, (3) the reputation of the barramundi brought to the domestic market recently and the related considerations of consumers, and (4) consumers' perceptions of the latest product development, smoked barramundi enriched with substances of positive nutritional effects (e.g. vitamin complex, pumpkin-seed oil, Gingko biloba extract, Sylibum marianum oil, etc.) Our findings suggest that consumers' perceptions of the barramundi were positive as they positioned this fish species as an attractive, premium category product. The product development, i.e. the smoked barramundi fillet, as a functional food, was well received by consumers. The target audience had already tasted smoked fish earlier, and they were satisfied with the taste of the new premium product. It is important to stress that the respondents lacked a good understanding of the meaning of "functional foods"; however, they agreed with such kind of product developments. They mostly appreciated the components of functional foods with positive and preventive effects on heart and eye health. On the basis of the research it can be concluded that product development is on the right track, it fulfils all the habits, expectations and demands of the target audience related to fish consumption.

KuLCSSZAVAK: termékfejlesztés, füstölt barramundi filé termékek, kóstoltatás, fogyasztói megítélés
KEYwORDS: product development, smoked Asian Sea Bass (Barramundi) filet products, tasting, consumer preferences

JELKóD: Q13, P46 


\section{BEVEZETÉS - INTRODUCTION}

\subsection{A hal szerepe az egészségtudatos táplálkozásban - Role of the Fish in the Health and Nutrition Awareness}

Az élelmiszeripar globális jelentősége manapság egyre inkább felértékelődik, köszönhetően a világméretű élelmiszerigény ugrásszerű növekedésének. Már nem az a fő probléma, hogy az élelmiszertermelésben és -feldolgozásban túltermelés figyelhető meg, hanem kulcskérdéssé vált az élelmiszerellátás biztonsága. Az időjárási viszontagságok, a globális felmelegedés és a fertőzések miatt a termelés évről évre nehézségekkel küzd, nem tud lépést tartani a nagymértékü kereslettel (PUSKA et al., 2003). Az elmúlt években világviszonylatban a fogyasztói igények terén is változás figyelhető meg, melyet a civilizációs betegségek rohamos terjedése hívott életre, hiszen egyre több a cukorbetegséggel, szív- és érrendszeri betegséggel és különböző ételallergiával küzdők száma. Ezek együttesen a mai napig új kihívások elé állították és állítják az élelmiszeripart, hiszen olyan termékek fejlesztése szükséges, melyek egészségvédő hatásuknak köszönhetően lassítják a betegségek terjedését, javítják a fizikai és mentális jólétet és akár gyógymódot is jelenthetnek egyes betegek számára (MENRAD, 2003).

Az egészségtudatosság előretörésének hatására az élelmiszeripar elkezdett olyan élelmiszereket gyártani, melyek megfelelő élvezeti értéket jelentenek étkezés közben, s emellett még az emberi egészség számára is pozitív előnnyel rendelkeznek, mint például a zsírtartalom csökkentése, a cukor elhagyása és egyes ásványi anyagokban gazdag termékek fogyasztása (SZAKÁLY, 1994). Az ehhez hasonló öszszetevőjü élelmiszereket az ágazat funkcionális élelmiszereknek nevezte el, s funkcionális élelmiszernek minősül a szakirodalom szerint „Minden olyan/bármilyen természetes vagy iparilag előállított élelmiszer, amely a benne lévő tápanyagokon túl egy, vagy több ún. bioaktív (fokozottan egészségvédő) anyagot is tartalmaz" (SZAKÁLY és SCHÄFFER, 2006). A funkcionális élelmiszerek piaci részesedése évről évre növekszik, s egyre inkább az élelmiszeripar húzótermékeivé válnak (MENRAD,
2003; PISKÓTI et al., 2006). A fejlődés oka, hogy az emberek egyre inkább úgy vélik, hogy az általuk fogyasztott élelmiszerek közvetlenül hozzájárulnak az egészségük megőrzéséhez, javításához (MOLLET és ROWLAND, 2002; YOUNG, 2000; BARNA, 2007; MENDIS et al., 2011).

Az egészséges táplálkozásra nagy hangsúlyt fektetők étrendjében rendszeresen jelen van a hal, hiszen a halhúsban sok létfontosságú tápanyag található, könnyen emészthető, nagy arányban tartalmaz teljes értékü fehérjét, és szinte az összes vitamin megtalálható benne. A halak elsősorban kedvező fehérje- és olajtartalmuk miatt vannak jelen az egészséges élelmiszerek körében, s jelentős bioaktív komponens-tartalmuk miatt funkcionalitással is bírnak. A feldolgozási folyamat során a termék olyan pozitív élelmi hatású anyagok hozzáadásával gazdagítható, melyeknek hatására a halhús fogyasztói megítélése javítható, különös tekintettel az egészségtudatos fogyasztói rétegre (CARECHE, 2010).

Az ENSZ Élelmezésügyi és Mezőgazdasági Világszervezete (FAO) 2012-es adatai alapján a haltermelés globális mennyisége 158 millió tonna volt, melynek közel 60\%-a halászat, 40\%-a pedig az akvakultúra eredménye. 2012ben a teljes haltermelés 86\%-a (136,2 millió tonna) került emberi fogyasztásra, elsősorban frissen, feldolgozatlanul értékesített termékként, a többi 14\% (21,7 millió tonna) pedig nem élelmiszeripari, ún. nonfood felhasználásra, elsősorban takarmány-alapanyagként használt hallisztet vagy halolajat készítettek belőle (FAO, 2014).

$\mathrm{Az}$ akvakultúra elsődlegesen az ázsiai országokban jelentős, hiszen 2012-ben a halmennyiség közel 70\%-a ezekből az országokból került ki. Az akvakultúrás haltermelésben meghatározó országok: Kína, Indonézia, az Amerikai Egyesült Államok, India és Peru. Halászat tekintetében Oroszországon kívül Norvégia és Izland tekinthető Európa legnagyobb halmenynyiségét kifogó országainak, hiszen ezen térségek fogásmennyisége éves szinten meghaladja az 1 millió tonnát. Ezzel szemben az Európai Unió tagországainak kifogott halmennyisége jellemzően csökken. 2012-ben ez hozzávetőlegesen mintegy 5 millió tonna volt, melynek döntő többsége az északi partvidékekról szár- 
mazott. A teljes halászott és akvakultúrákban előállított mennyiség mintegy 37\%-a került exportra, melynek értéke 129,2 milliárd USD volt 2012-ben. Export tekintetében messze a legfontosabb exportőr Kína, majd ôt követi Norvégia, Thaiföld és Vietnam. Import esetében a legjelentősebb területeknek számítanak a fejlett országok, mint például az Amerikai Egyesült Államok, Japán és az Európai Unió (FAO, 2014).

\subsection{A hal és halászati termékek fogyasztása - Consumption of Fish and Fisheries Products}

Hazánkban az élelmiszerfogyasztással kapcsolatban először a 19. század '80-as éveiben jelent meg átfogó tanulmány. KELETI Károly 1889-ben a „Magyarország népességének élelmezési statisztikája physiológiai alapon" címú munkájában leírja, hogy a múlt század második felében körülbelül 1,5 kg/fó volt az éves halfogyasztás hazánkban. Ez a fogyasztás azonban elsősorban természetes vízi halászatból származott és elenyésző hányadát jelentette a halastavi termelés. Ebben az időszakban a halhús fontos népélelmezési szerepet is betöltött, mivel egyes néprétegeknek az egyik legolcsóbban elérhető húsféleséget jelentette.

A Központi Statisztikai Hivatal adatai szerint hazánkban az egy főre eső hal- és halászati termék ellátás lassú, de következetes gyarapodást mutatott az elmúlt tíz évben, mindamellett, hogy ebból az utolsó 3 évben már inkább stagnálásról beszélhetünk, amit az 1. ábra szemléltet. Az egy fơre jutó összes halfogyasztásunk 3,5-3,7 kg/fö/év ${ }^{1}$ között ingadozott, mely az összes húsfogyasztásunkon belül mintegy 5,0-5,5\%-ot jelent csontoshúsra vetítve (KSH, 2013). Ez a mennyiség egyaránt magában foglalja a saját termelésű, valamint import eredetű halászati termékeket. A hazai termelés elsősorban élő hal formájában, míg az import főleg feldolgozott formában (pl. konzerv, mélyhútött konyhakész, mélyhütött filé, pácolt stb.) kerül a fogyasztók asztalára. A mintegy 3,5-3,7 kg/fó/év halfogyasztásunknak közel egyharmada a karácsony előtti időszakra esik. A halételek készítése és rendszeres fogyasztása területenként jelentősen változik, mivel vannak olyan megyék, városok, ahol a hal mindennapi eledel. Például a bajai átlagpolgár a szakértői becslések szerint mintegy 40,0-45,0 kg halat eszik évente, amely több mint tízszerese a magyar értéknek (MAHAL, 2015).

Napjainkban Európában mintegy 24,o kg/ fő az éves fogyasztási szint halból, illetve halászati termékekból, ezért a magyar fogyasztási színvonal mélyen az európai átlag alatt marad. Egyes becslések szerint hazánkban halhúsból minimum $10 \mathrm{~kg} /$ fó éves fogyasztási színvonal lenne megfelelő táplálkozás-élettani szempontból, mivel a szív- és érrendszeri betegségek világranglistáján dobogós helyet foglalunk el.

Az egy fóre jutó hal és halászati termékek - beleértve az akvakultúrás termékeket is - fogyasztásában jelentős különbségeket tapasztalhatunk az egyes európai tagállamok között. Hagyományosan magas azokban az országokban ez az érték, ahol régmúltból meghatározó tengeri halászati hagyományokkal rendelkeznek. Megjegyzendő azonban, hogy nem minden kiterjedt tengerparti zónával rendelkező országról mondható ez el. A 15 kg/fó/év alatti értékekkel elsősorban a közép-kelet- európai országok bírnak, amelyek többségükben nem rendelkeznek tengerparttal, de figyelemre méltó az a tény is, hogy közöttük is jelentősek a különbségek. Az észak-nyugat-európai országok rendre 15-30 kg/fó értékkel szerepelnek és elsősorban a dél-európai országok és pl. Franciaország déli provinciái azok, ahol ezt meghaladó adatok a jellemzőek. Az Európai Unión belül Portugália és Spanyolország kiemelkedik a $40 \mathrm{~kg}$ /fő/év értéket meghaladó hal és halászati termékek fogyasztásával, míg ugyanebben az összehasonlításban Magyarország, Bulgária és Románia a sereghajtó rendkívül alacsony, $5 \mathrm{~kg} /$ fö/év értéket el nem érő, illetve alig meghaladó adataival (EURÓPAI BIZOTTSÁG TENGERÜGYI ÉS HALÁSZATI FÖIGAZGATÓSÁG, 2016).

A világ magas halhúsfogyasztása mellett hazánkban a halfogyasztás elég csekély mértékünek mondható. 
A FAO adatai szerint 2010-ben a világon egy före jutó halfogyasztás éves szinten $18,4 \mathrm{~kg}$ volt, ezzel szemben Magyarországon 5,1 kg/fö/ év. Ezzel a fogyasztási mennyiséggel az európai országok halfogyasztásának rangsorában az utolsó előtti helyen állt hazánk (FAO, 2012).

\section{1. ÁBRA}

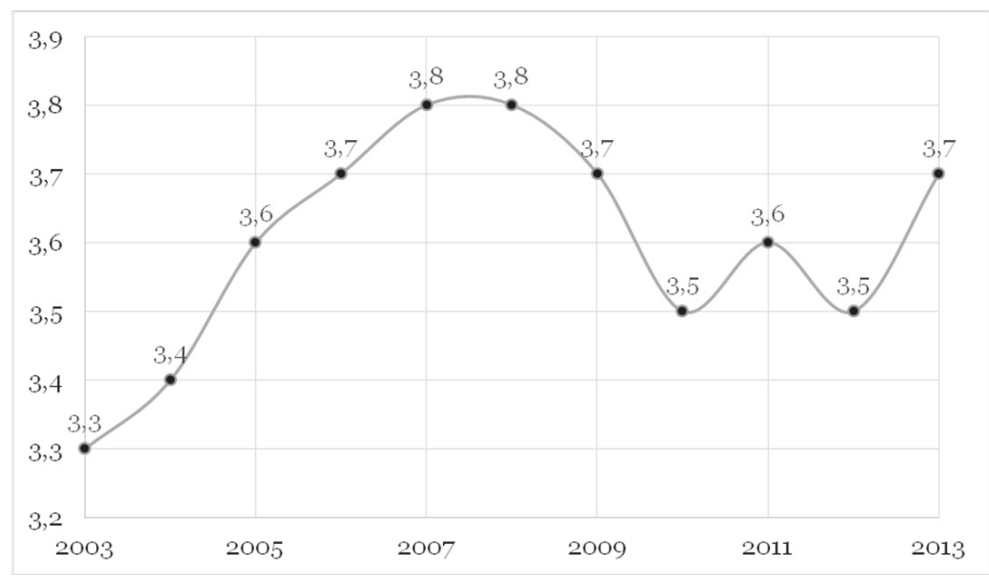

Forrás (Source): KSH, Saját szerkesztés, 2013 (KSH, Own construction, 2016)

Halfogyasztás Magyarországon 2003-2013

FIG. 1 Megjegyzés (Notes): Me.: kg/fő/év (kilogram/capita/year)

\subsection{Témafelvetés és célkitüzések - Research Theme and Objectives}

Egy adott ország halászati termékeinek fogyasztását nagyon sok tényező befolyásolja és ezeknek a relatív súlya is rendre különböző. Az európai uniós országokban, közöttük Magyarországon jellemző legfontosabb tendenciákat általánosan befolyásoló közvetett tényezők a következők: (1) biztonságos élelmiszer iránti igény; (2) egészséges élelmiszer iránti kereslet; (3) minőség iránti igény; (4) kényelmi termékek iránti igény; (5) természetközeli gazdálkodásból (bio/öko) származó termékek iránti igény; (5) vallás és a hagyományok; (6) földrajzi eredet. A fogyasztási szokások és a fogyasztói viselkedések egy bonyolult soktényezős rendszerben alakulnak ki. Tény, hogy a halhús-fogyasztási szokásokat nagyon sok makro és mikro szinten ható tényező együttes hatása alakítja ki. A legfontosabb közvetlenül ható befolyásoló tényezők a következők: (1) árak; (2) hagyományok; (3) ismertség/általános kedveltség; (4) divat; (5) ízlés; (6) elérhetőség; (7) személyes tényezők; (8) reklám; (9) csomagolás; (10) csa- ládi szokások/hagyományok (PANYOR, 2007). Egy adott piacon újszerűnek minősülő halfaj bevezetése, a potenciális fogyasztói csoportokkal való megismertetése nem egyszerü feladat, mert nem elég jó minőséget előállítani és azt a fogyasztók számára elérhetővé tenni, azt minden esetben meg is kell ismertetni. A mi esetünkben a barramundi az, az egyébként Ázsiában, Ausztráliában és Nyugat-Európában széles körben ismert és elismert prémium minőségű halfaj, amit a hazai fogyasztók számára is elérhetővé tett a Jászkiséri Halas Kft. a 2011. évtől kezdődően. A szóban forgó halfaj magyarországi piacra történő bevezetését követően 2013-ban termékinnováció keretein belül olyan - potenciálisan funkcionális élelmiszernek minősülő - füstölt halterméket állítottunk elő a Debreceni Egyetem és az UNIO-Seafood Kft. munkatársaival együttmúködve, ami a füszereken kívül különböző gyógynövénykivonatokat és pozitív élettani hatású olajokat tartalmazott $^{2}$.

Az újonnan kifejlesztett füstölt haltermékek, valamint a barramundi halfaj általános fogyasztói megítélésével kapcsolatosan ter-

${ }^{2}$ Ezt a munkát az NTP TECH_o9-A3-2009-0235 „Exportképes halfajok (Barramundi, Vörös árnyékhal) termeléstechnológiájának komplex fejlesztése" című projekt támogatta. 
mékkóstoltatással egybekötött primer vevői megkérdezést végeztünk standardizált kérdőívek alkalmazásával.

A felmérésünk alapvető célja egy új, potenciálisan funkcionális halterméknek minősüló termékcsalád vásárlók körében történő tesztelése volt. A termékfejlesztési koncepció alapja az volt, hogy a legnépszerúbb, gyógyszertári/ drogériai forgalomban is kapható táplálékkiegészítők hatóanyagai (pl. ginkóbiloba-kivonat, máriatövismag-olaj; tökmagolaj, Q10; vitamin komplex stb.) kerüljenek bele egy füstölt barramundi filébe úgy, hogy az egy felnőtt számára ajánlott napi mennyiség fele legyen egy „tenyérnyi” füstölt filében megtalálható. A vizsgálatot megelőzően ún. meleg füstölést követően a kb. 45-50 C ${ }^{\circ}$-os felszíni hőmérsékletü filére vitték fel a vizes/olajos oldatot, amit a filé nagyon gyorsan magába szívott a szikkadás/ pihentetés során. A próbagyártást követően került sor a fogyasztói tesztelésre, melynek elsődleges célja az volt, hogy megtudjuk, hogyan viszonyulnak a hazai potenciális fogyasztók ehhez az új termékcsaládhoz.

\section{ANYAg ÉS MóDSZER - MATERIAL AND METHOD}

Az ausztrál süllő/barramundi halfaj magyarországi piacra történő 2011. évi bevezetése után a termék funkcionális élelmiszer irányába történő fejlesztésével kapcsolatban termékkóstoltatással egybekötött primer, nem reprezentatív piackutatást végeztünk kvantitatív módszerrel, standardizált kérdőívek alkalmazásával.

A kérdőíves felmérés során alapsokaságnak tekintettük a halfogyasztó, bevásárló közönséget, melynek kiszúrését szolgálta maga a kóstoltatás, annak helyszíne, valamint a kérdőív 1. kérdése, mely a halfogyasztás gyakoriságára kérdez rá. Ez utóbbi alapján a „Sohasem fogyasztok halat" kategóriát megjelölő válaszadókat automatikusan kizártuk a megkérdezésból (ez 5 esetben történt meg).

A megkérdezést 2012 szeptemberében végeztük, kérdezőbiztosok (doktorandusz hallgatók) segítségével, két helyszínen, a debreceni és a budaörsi Auchan hipermarketekben. A kóstoltatás során a megkérdezetteknek lehetőségük volt megízlelniük a funkcionális élelmiszerré fejlesztett, füstölt barramundi prototípusát a kereskedelmi forgalomba hozatal előtt. A kóstolás során nyert benyomásukat a válaszadók a kérdőív megfelelő kérdéseiben értékelhették. A felmérés során 209 db kérdőív kitöltetése valósult meg, amelyből az adatrögzítést követően 202 db (Budaörs: 127 db; Debrecen: $75 \mathrm{db}$ ) bizonyult értékelhetőnek ${ }^{3}$. A kérdőívek kiértékelését SPSS 13.0 statisztikai programcsomag segítségével végeztük.

$\mathrm{Az}$ adatrögzítést közvetlenül az adattisztítás folyamata követte, a kérdőíves megkérdezés és az adatbevitel során keletkezett hibák, az outlierek kiszürése érdekében, amihez alapfokú leíró statisztikai módszereket alkalmaztunk (minimum, maximum, átlag, szórás, megoszlás).

A szignifikancia-vizsgálatok elvégzéséhez több szempont szerint szegmentáltuk a kérdőíves felmérés válaszadóit. Egyrészt a kérdőíves megkérdezés végén szegmentáló kérdéseket intéztünk a megkérdezettekhez, másrészt pedig a kérdőív bizonyos kérdései alkalmasnak bizonyultak a csoportképzésre és ezáltal öszszefüggések feltárására. Felhívjuk ugyanakkor a figyelmet arra, hogy a szegmentáló kérdések többségénél (a 4, illetve annál több válaszlehetőséget tartalmazó kérdések esetében) a kérdőívben szereplő kategóriákat - elsősorban azokat, amelyeket kevésbé voltak jellemzők, vagyis kevés jelölést kaptak - összevontuk (ezekre az egyes szegmentáló kérdések ismertetésénél felhívjuk a figyelmet). Ennek az összevonásnak az oka, hogy kis létszámú a mintasokaság, a túl sok változó összevetése pedig nagyon szétaprózza a mintát, ami ilyen kis létszámnál jelentősen torzítja a szignifikancia-vizsgálatok végeredményét.

Nemek szerint a megkérdezettek 59,9\%-a nő, 40,1\%-a férfi volt. A válaszadók legmagasabb iskolai végzettsége alapján 4 csoportot alakítottunk ki. Alapfokú végzettséggel rendelkezik a megkérdezettek 4,3\%-a, középfokú (szakmunkás) végzettséggel 7,6\%-uk, középfokú (szakközépiskola, gimnázium) 37,8\%-uk és felsőfokú végzettséggel 50,3\%-uk.

${ }^{3}$ Mivel a célunk az volt, hogy minél több információt kapjunk a célközönség halfogyasztási szokásairól és a termékfejlesztés fogadtatásáról, ezért nem tekintettük kizáró tényezőnek azt, ha a válaszadó bizonyos kérdésekre nem válaszolt, vagy ha nem sikerült teljesen végigkérdezni a kérdőívet. Ezt minden kérdésnél jeleztük az elemszám (N) feltüntetésével. 
A státusz, fó tevékenység szerint a megkérdezetteket 4 csoportba osztottuk: aktív fizikai dolgozó a válaszadók 15,6\%-a, aktív szellemi dolgozó 52,2\%-a, nyugdíjas 18,8\%-uk és egyéb (GYES/GYED, háztartásbeli, tanuló, munkanélküli, egyéb) kategóriába tartozik 13,4\%-uk.

Életkor alapján 3 csoportot alakítottunk ki, a 30 év alatti korcsoportba tartozik a megkérdezettek 15\%-a, a 30-50 év közötti korcsoportba $44,4 \%$-uk és 50 év feletti a válaszadók 40,6\%-a.

A kérdőív utolsó szegmentáló típusú kérdése arra vonatkozott, hogy az egy főre jutó nettó jövedelem, illetve az életvitel alapján a meghatározott kategóriák közül melyikbe sorolja be magát a válaszadó (jelentősen átlag alatt, valamivel az átlag alatt, valamivel az átlag felett, jelentősen az átlag felett). Előfordultak olyan szegmensek, melyek alig képviseltek néhány főt, így egyes szegmensek összevonásra kerültek. Ily módon 2 kategóriát különböztettünk meg nettó jövedelem és életvitel alapján: átlagos jövedelmi színvonalúnak a válaszadók 75,0\%-a vallotta magát, átlag feletti jövedelmi helyzetünek 25,0\%-a. Az átlag alatti (202 főből 9 fó), és a nem tudom/nem válaszol (202 fóből 10 fó) kategóriákat választókat kizártuk a szignifikancia-vizsgálatból.

A kérdőív speciális, szegmentáló típusú kérdései mellett 2 további kérdést is felhasználtunk szegmentálás céljából. Az egyik a megkérdezés helyszínét biztosító városok (Debrecen és Budaörs), míg a másik a kérdőív azon kérdése, amely a halfogyasztás gyakoriságára kérdez rá. A változók összevonása után a válaszadók $61,4 \%$-a ritkán fogyaszt halat, 38,8\%-uk pedig többé-kevésbé rendszeres halfogyasztónak tartja magát. A szignifikancia-vizsgálatok során ezt az összevont változatot alkalmaztuk.

\section{EREDMÉNYEK - Results}

A kérdőív összesen 28 kérdést tartalmazott, melyből 23 a halfogyasztási szokásokra kérdezett rá, valamint a megkóstolt halételek értékelését tette lehetővé, míg 5 szegmentáló jellegü volt. A jelen cikk keretei között nincs lehetőségünk minden kérdés kiértékelését bemutatni, ezért szelektáltunk.
Az, hogy egy új halfaj piaci bevezetése során milyen formában kerüljön a fogyasztók asztalára, kiemelt jelentőségü, ezért az egyik kérdésünk - egy, a barramundit ábrázoló kép segítségével - azt tudakolta a válaszadóktól, hogy milyen formában vásárolná szívesebben a halat (egészben vagy filé formájában). A termékfejlesztés szempontjából kedvezően alakultak a válaszok, hiszen a megkérdezettek 77,1\%-a filé formájában vásárolná szívesen a barramundit, és csupán 16,9\%-uk adagos halként. A foglalkozás szerinti csoportosítás eredményeként megállapítottuk, hogy az aktív fizikai dolgozók közel fele $(41,4 \%)$ adagos halként vásárolná szívesen a barramundit és $52 \%$-uk filé formájában. Ezzel ellentétben a többi foglalkozási csoportba tartozók esetén (aktív fizikai dolgozó, nyugdíjas egyéb) az adagos halra voksolók aránya $20 \%$ alatt, a filét választóké 70\% fölött alakult (Pearson-féle Khi-négyzet próba, $\mathrm{p}=0,006)$.

Szerettük volna megtudni, hogy a megkérdezettek közül találkozott-e már valaki az „asc” logóval (2. ábra), és ha igen, tudja-e, hogy mit tanúsít. Ez azért is fontos, mert bizonyos kiskereskedelmi láncoknál elvárás a beszállítókkal szemben, hogy ezzel a tanúsítvánnyal rendelkezzen az adott haltermék.

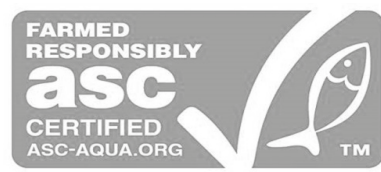

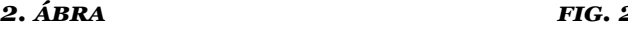 \\ Az „Aquaculture Stewardship Council” logója \\ (Logo of the Aquaculture Stewardship Council)}

Forrás (Source): http://www.asc-aqua.org/

$\mathrm{Az}$ Aquaculture Stewardship Council („asc”) küldetése környezeti és társadalmi szempontból fenntartható akvakultúrák létrehozása. Néhány éves időtávlatban az „asc” a világ vezető tanúsítványi és címkézési rendszerét dolgozta ki a felelősségteljes haltermelés elérése érdekében. Az „asc” célkitüzése, hogy növelje azon akvakultúrás termékek piaci elérhetőségét, melyek igazoltan fenntartható és felelős termelés eredményei. Az „asc” logóval ellátott termékek, tehát maga az „asc” megjelölés arról 
biztosítja a fogyasztót, hogy a címkével ellátott termék előállítása során megfelelt az „asc” által előírt standardoknak. Az „asc” logója a felelősségteljes gazdaságokból származó ún. fenntartható módon előállított haltermékeket jelöli. A logóval ellátott termékekkel olyan fogyasztói szegmenset céloznak meg, ahol növekvő igény mutatkozik a tudatosan és felelősen előállított halászati termékek iránt.

$\mathrm{Az}$ „asc” logó ismertsége nagyon alacsony volt a megkérdezettek körében, mivel a válaszadók 87,2\%-a nyilatkozott nemmel a kérdésre, és csupán 7,0\%-uk válaszolta azt, hogy látta már valamilyen terméken, míg 5,9\%-uk nem tudta eldönteni, azaz bizonytalan volt abban, hogy látta-e. A megkérdezés helyszíne szerinti szegmentáció során továbbá megállapítottuk, hogy a „nem”-mel válaszolók aránya közel azonos volt a debreceni és a budapesti megkérdezettek körében (85,0\% és 89,0\%). A folytatásként feltett, „Ha igen, tudja-e, hogy mit igazol?” Kérdésre mindösszesen 5 fő válaszolt a megkérdezettek közül: 4 fő nyilatkozta azt, hogy nem tudja, mit igazol a tanúsítvány, egyetlen fő pedig azt, hogy „milyen minőségü a termék".

A kóstoltatással a termékprototípust teszteltük. A kérdőív ide kapcsolódó első kérdésével azt szerettük volna megtudni, hogy a megkérdezettek kóstoltak-e már valaha füstölt halat. A válaszadók 86,6\%-a kóstolt már életében füstölt halat, 12,8\%-uk viszont még sohasem. Ez azt jelenti, hogy a potenciális vásárlói célcsoport számára nem lesz ismeretlen az a forma (füstölt hal), ahogyan a kifejlesztett terméket kínálni fogjuk, a kérdés csupán az, hogy a korábban kóstolt füstölt hal milyen benyomást tett a válaszolókra. A megkérdezettek legmagasabb iskolai végzettsége alapján szegmentálva (Pearson-féle Khi-négyzet próba, $\mathrm{p}=\mathrm{0}, 003$ ) megfigyeltük, hogy az iskolai végzettség növekedésével emelkedett azoknak a válaszadóknak az aránya, akik már kóstoltak korábban füstölt halat. A kérdés folytatása a bevezetni kívánt termék szempontjából kiemelten fontos, hi- szen azt kérdeztük a válaszadóktól, hogy ha már kóstoltak korábban füstölt halat, akkor mi volt a benyomásuk (ízvilág, megjelenés stb.). A válaszok alapján a hipotézisünk, mely szerint a füstölt hal ízletes, alátámasztást nyert, hiszen a megkérdezettek 93,8\%-a nyilatkozta azt, hogy „ízletes volt” a korábban kóstolt füstölt halétel. Mindössze a válaszadók 2,5\%-a mondta azt, hogy „nem ízlett” neki ez az ételféleség, 3,8\%uk pedig nem tudta eldönteni.

A kérdőív egyik kérdése rákérdez arra, hogy szívesen vásárolna-e a válaszadó olyan füstölt halat, ami egyben funkcionális élelmiszer is. Az eredmények alapján a megkérdezettek 88,6\%-a szívesen vásárolna funkcionális élelmiszernek minősülő füstölt halat, míg 8,6\%uk nem, 2,7\%-uk pedig nem tudja eldönteni. A szegmentálás során nem tudtunk szignifikáns differenciát megállapítani egyik esetben sem.

A funkcionális élelmiszer irányába történő termékfejlesztés fogyasztói megítélésének felmérésére $4 \mathrm{db}$ állítást soroltunk fel és arra kértük a válaszolókat, hogy értékeljék ezeket egy 1-től 5-ig tartó skálán - vagyis azt, hogy mennyire értenek egyet a kijelentésekkel (1: egyáltalán nem ért egyet, 5: teljes mértékben egyetért, o: nem tudja eldönteni). Az állításokkal arra kerestük a választ, hogy helyes termékfejlesztési koncepciónak tartják-e a válaszadók azt, hogy a füszerezésen kívül a füstölt hal gyógynövénykivonatokat, vitaminokat, pozitív hatású élelmi olajakat, illetve élettanilag kedvező hatású egyéb komponenseket is tartalmaz.

Az 1. táblázat tartalmazza az egyes kijelentések fogyasztói értékelésének átlagát. Látható, hogy a fưszerezésen kívül legnagyobb mértékben a „pozitív hatású élelmi olajok” komponenst támogatják a megkérdezettek $(4,29)$, amit az is alátámaszt, hogy a szórásérték is itt a legalacsonyabb (1,37). Legkevésbé a gyógynövénykivonatok alkalmazását helyeselték a válaszadók $(3,66)$, ami nem jelenti azt, hogy egyáltalán nem támogatták, hiszen itt volt a legnagyobb a válaszok szórása. 
A termékfejlesztési koncepció megítélése (Judgement of the Product Development Concept)

\begin{tabular}{|c|c|c|c|c|c|c|c|}
\hline \multirow[b]{2}{*}{ Állítások (Statements) } & \multicolumn{7}{|c|}{ Statisztikai mutatók (Statistical Indicators) } \\
\hline & $\mathbf{N}$ & NTE & $\mathbf{\Sigma N}$ & Min. & Max. & $\begin{array}{l}\text { Átlag* } \\
\text { (Mean) }\end{array}$ & $\begin{array}{c}\text { Szórás* } \\
\text { (Standard } \\
\text { Deviation) }\end{array}$ \\
\hline $\begin{array}{l}\text { Helyes termékfejlesztési koncepció, } \\
\text { hogy a füszerezésen kívül a füstölt hal } \\
\text { gyógynövénykivonatokat is tartalmaz } \\
\text { (The conception of product } \\
\text { development can be considered right, } \\
\text { if the smoked fish is not only seasoned, } \\
\text { but also contains herbal extracts) }\end{array}$ & 180 & 3 & 183 & 1 & 5 & 3,66 & 1,68 \\
\hline $\begin{array}{l}\text { Helyes termékfejlesztési koncepció, } \\
\text { hogy a füszerezésen kívül a füstölt hal } \\
\text { vitaminokat is tartalmaz } \\
\text { (The conception of product } \\
\text { development can be considered right, } \\
\text { if the smoked fish is not only seasoned, } \\
\text { but also contains vitamins) }\end{array}$ & 181 & 2 & 183 & 1 & 5 & 3,92 & 1,62 \\
\hline $\begin{array}{l}\text { Helyes termékfejlesztési koncepció, } \\
\text { hogy a füszerezésen kívül a füstölt } \\
\text { hal pozitív hatású élelmi olajokat is } \\
\text { tartalmaz (The conception of product } \\
\text { development can be considered right, } \\
\text { if the smoked fish is not only } \\
\text { seasoned, but also contains dietary } \\
\text { oils of positive effects) }\end{array}$ & 181 & 2 & 183 & 1 & 5 & 4,29 & 1,37 \\
\hline $\begin{array}{l}\text { Helyes termékfejlesztési koncepció, } \\
\text { hogy a füszerezésen kívül a füstölt } \\
\text { hal élettanilag kedvező hatású egyéb } \\
\text { komponenseket (pl. ásványi anyagok, } \\
\text { mikroelemek stb.) is tartalmaz } \\
\text { (The conception of product } \\
\text { development can be considered right, } \\
\text { if the smoked fish is not only seasoned, } \\
\text { but also contains other components of } \\
\text { physiologically favourable effects } \\
\text { (e.g. mineral, microelements, etc.)) }\end{array}$ & 178 & 4 & 182 & 1 & 5 & 3,99 & 1,57 \\
\hline
\end{tabular}

"N elemszám alapján ( $\mathrm{N}=$ válaszolt a kérdésre). NTE = nem tudja eldönteni; According to $N$ item. $N=$ she/he answered the question; $N T E=$ she/he can not decide it

Forrás (Source): Saját szerkesztés, 2012 (Own construction)

A kérdőív következő kérdése azoknak a válaszadóknak szólt, akik a („Szívesen vásárolna funkcionális élelmiszernek minősülő füstölt halat?”) kérdésre igennel válaszolt, mivel ezek az emberek lesznek a potenciális vásárlói a kifejlesztett terméknek. A termék csomagolásának tartozéka egy matrica/logó, ami arra hívja fel a fogyasztó figyelmét, hogy az adott füstölthal-termék milyen funkcionális élelmiszer-komponenst tartalmaz, illetve milyen speciális egészségvédő hatással bír. A kérdezőbiztosok összesen 12 különböző logót mutattak a válaszadóknak (3.ábra). 
A kérésünk az volt a válaszadók felé, hogy jelöljék meg sorrendben, melyik hármat választanák leginkább a logókkal megjelölt termékek közül. Ennél a kérdésnél - amellett, hogy megszámoltuk, hogy az egyes logókat hányszor nevezték meg a válaszadók - a sorrendiséget is figyelembe vettük (hányadik helyre tették a lehetséges háromból). A rangsort úgy állítottuk fel, hogy elsődlegesen a jelölések számát (N), másodlagosan az átlagértékeket vettük figyelembe.
(L1)

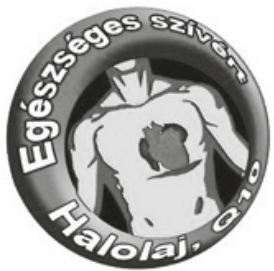

(L4)

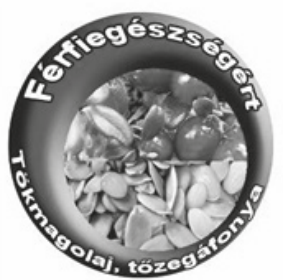

(L7)

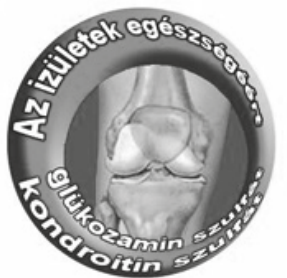

(L10)

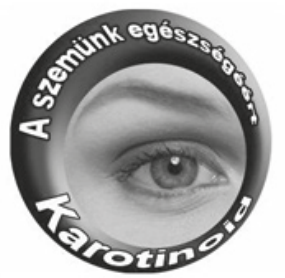

(L11)

(L2)

(L5)

(L8)
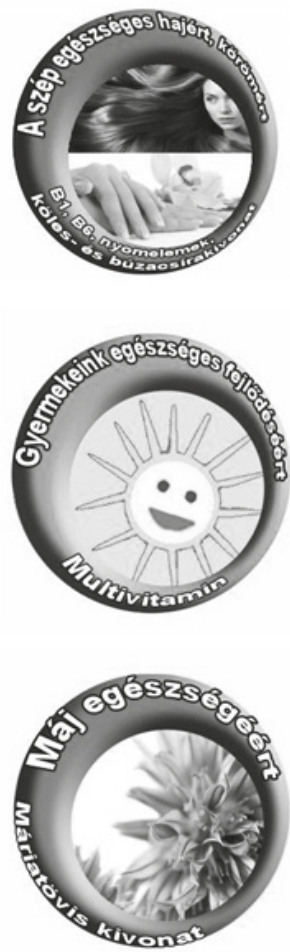

(L9)

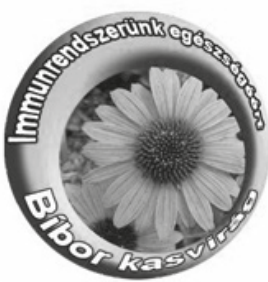

(L6)

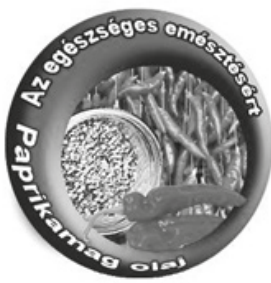

(L3)

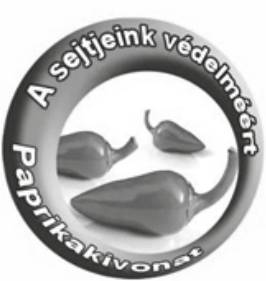

(L12)

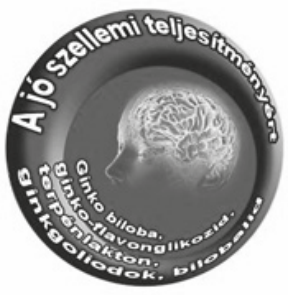

FIG. 3

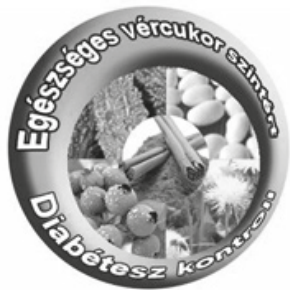

3. ÁBRA

A bemutatott termékprototípusokon használt funkcionális élelmiszer-komponens logók (Functional Food Components Logos on Prototypes)

Forrás (Source): Saját szerkesztés, 2012 (Own construction) 
A logókkal megjelölt termékek fogyasztói preferenciái

(Consumer Preferences of Products Marked with Logo)

\begin{tabular}{|c|c|c|c|c|c|c|}
\hline \multirow[b]{2}{*}{ Kategória (Category) } & \multicolumn{6}{|c|}{ Statisztikai mutatók (Statistical Indicators) } \\
\hline & $\begin{array}{l}\text { Fó } \\
(\mathbf{N})\end{array}$ & $\%$ & Min. & Max. & $\begin{array}{c}\text { Átlag } \\
\text { (Mean) }\end{array}$ & $\begin{array}{c}\text { Szórás } \\
\text { (Standard } \\
\text { Deviation) }\end{array}$ \\
\hline L1 (Egészséges szívért) (For healthy heart) & 89 & 20,60 & 1 & 3 & 1,69 & 0,81 \\
\hline $\begin{array}{l}\text { L10 (A szemünk egészségéért) } \\
\text { (For health of our eyes) }\end{array}$ & 60 & 13,89 & 1 & 3 & 2,08 & 0,83 \\
\hline $\begin{array}{l}\text { L12 (A jó szellemi teljesítményért) } \\
\text { (For good mental performance) }\end{array}$ & 59 & 13,66 & 1 & 3 & 2,15 & 0,78 \\
\hline $\begin{array}{l}\text { L5 (Gyermekeink egészséges fejlődéséért) } \\
\text { (For Healthy development of our children) }\end{array}$ & 39 & 9,03 & 1 & 3 & 1,85 & 0,84 \\
\hline $\begin{array}{l}\text { L11 (Egészséges vércukorszintért) } \\
\text { (For healthy blood sugar level) }\end{array}$ & 32 & 7,41 & 1 & 3 & 2,06 & 0,76 \\
\hline $\begin{array}{l}\text { L7 (Az ízületek egészségéért) } \\
\text { (For the healthy joints) }\end{array}$ & 32 & 7,41 & 1 & 3 & 2,19 & 0,78 \\
\hline $\begin{array}{l}\text { L3 (Az egészséges emésztésért) } \\
\text { (For the healthy digestion) }\end{array}$ & 27 & 6,25 & 1 & 3 & 2,07 & 0,83 \\
\hline $\begin{array}{l}\text { L6 (Immunrendszerünk egészségéért) } \\
\text { (For our immune system health) }\end{array}$ & 24 & 5,56 & 1 & 3 & 2,00 & 0,78 \\
\hline L4 (Férfiegészségért) (For men's health) & 21 & 4,86 & 1 & 3 & 1,95 & 0,86 \\
\hline L8 (A máj egészségéért) (For liver health) & 19 & 4,40 & 1 & 3 & 2,00 & 0,67 \\
\hline $\begin{array}{l}\text { L2 (A szép, egészséges hajért, körömért) } \\
\text { (For the beautiful healthy hair and nails) }\end{array}$ & 15 & 3,47 & 1 & 3 & 2,07 & 0,96 \\
\hline $\begin{array}{l}\text { L9 (A sejtjeink védelméért) } \\
\text { (For the protection of our cells) }\end{array}$ & 15 & 3,47 & 1 & 3 & 2,33 & 0,72 \\
\hline Összesen (Total) & 432 & 100,00 & - & - & - & - \\
\hline
\end{tabular}

Forrás (Source): Saját szerkesztés, 2012 (Own construction)

A 2. táblázat adatai alapján kijelenthetjük, hogy a válaszadók a logókkal megjelölt haltermékek közül sorrendben elsőként az L1 (egészséges szívért), másodikként az L1o (a szemünk egészségéért), harmadikként pedig az L12 (a jó szellemi teljesítményért) jelúeket választanák. A szignifikancia-vizsgálat eredménye a következő:

- Az L2 (A szép egészséges hajért, körömért) logót - a hipotézisünket alátámasztva elsősorban a nők választották (14,8\%) a férfiakkal ellentétben $(3,5 \%)$ (Pearson-féle Khi-négyzet próba, $\mathrm{p}=0,030)$.

- Az L3 (Az egészséges emésztésért) logót a budapesti válaszadók 25\%-a, míg a debreceniek 10\%-a sorolta a választottak közé (Pearson-féle Khi-négyzet próba, $\mathrm{p}=0,025)$.

- Az L6 (Immunrendszerünk egészségéért) logót elsősorban az aktív fizikai dolgozók $(36,4 \%)$ választották, legkevésbé az egyéb státuszúak (5\%) (Pearson-féle Khi-négyzet próba, $\mathrm{p}=0,018)$.

- Az L7 (Az ízületek egészségéért) logót a szakmunkás végzettségüek 60\%-a nevezte meg, míg az alapfokú végzettséggel rendelkezők közül senki (Pearson-féle Khi-négyzet próba, $\mathrm{p}=0,012$ ).

A termék csomagolásához kapcsolódó kérdés: „Mi az összbenyomása az új termékprototípusok csomagolásával kapcsolatosan?” Mi- 
vel ez nyitott kérdés volt, igazán sokféle választ kaptunk a megkérdezettektől, valamennyit bemutatni ugyanakkor itt nem áll módunkban. A válaszok alapján 4 kategóriát tudtunk kialakítani. Ez a fajta csoportosítás lehetővé tette, hogy a nyitott kérdésekre is lefuttassuk a szignifikancia-vizsgálatot. A válaszok csoportokba rendezése a kérdőíveket feldolgozó személy szubjektív megítélése alapján történt. A kialakított csoportok (néhány példával) a következók:

- pozitív (bizalomgerjesztô, dekoratív, jó, szép, tetszik, szimpatikus stb.);

- pozitív, kritikával (elegáns, de ne növelje az árat; jó, hogy látszik a termék; Omega3 is legyen feltüntetve; tetszik, de nem minden logó szimpatikus stb.);

- negatív (lehetne egyszerúbb, lehetne színesebb, nem figyelemfelkeltö, túl sötét, túl sok logó stb.);

- semleges (kettő is beleférne, közepes).

A válaszadók összbenyomása a termék csomagolásával kapcsolatban többnyire egyértelműen pozitív volt $(76,5 \%)$. Akadtak olyanok, akik a pozitív véleményük mellett kritikát is megfogalmaztak (10,8\%). A negatív véleményt képviselők aránya csupán 11,4\% volt, és mindössze a válaszolók 1\%-a nyilatkozott semlegesen a csomagolásról. Amire fel kell hívnunk a figyelmet, hogy a „pozitív, de kritikus” vélemények szinte mindegyike arra vonatkozott, hogy ugyan szép a csomagolás, de „ne drágítsa az árat”. Vagyis attól tartottak ezek a válaszadók, hogy a dizájn a termék árának rovására megy.

A korcsoportok szerinti szegmentáció Pearson-féle Khi-négyzet próbával, $\mathrm{p}=0,031$ valószínűségi szinten mutatott szignifikáns differenciát. Minél fiatalabb volt a válaszadó, annál könnyebben fogalmazott meg negatív kritikát $(21,7 \%)$ „kertelés nélkül”. Minél idősebb korosztályt képviselt a válaszadó, annál kevésbé nyilvánított ki egyértelmü nemtetszést, ugyanakkor egyre nagyobb arányban figyelhetünk meg ezeknél a korcsoportoknál „pozitív, de kritikus" véleményt. Ezek tulajdonképpen a diplomatikus, ún. „burkolt” bírálatok.

A következőkben a válaszadók általános véleményeit kívántuk felmérni a termékfejlesztéssel (új termékprototípusokkal) kapcsolatban. Ez a kérdés az előbb bemutatott kérdéshez hasonlóan nyitott kérdés volt, így a feldolgozása és a kiértékelése is a fentebb bemutatott módon történt. A kialakított 4 csoport is hasonló, mint az előző kérdésnél:

- pozitív (jó, finom, jó ötlet, ízletes, szimpatikus, tetszik stb.);

- pozitív, de kritikus (finom, csak borsos; jó, csak drága; tetszik, finom, jó ár kellene stb.);

- negatív (nem értek vele egyet, felesleges, gyanús, nem jó, méreg, mesterséges stb.);

- semleges (érdekes, nem árt, bizonytalan, nincs véleménye stb.).

A bemutatott termékfejlesztést a válaszadók többsége $(72,5 \%)$ pozitívnak ítélte meg, 13,7\%-uk fogalmazott meg negatív kritikát, 7,2\%-uk nyilatkozott ugyan pozitívan, de bírálóan és 6,5\%-uk semlegesen.

A kérdőíves megkérdezés utolsó momentuma a termékkóstoltatás volt, amikor lehetőségük nyílt a megkérdezetteknek megízlelni a füstölt barramundit, majd ezt követően a benyomásuk alapján értékelni azt. Az értékeléshez különböző állításokat soroltunk fel a termék illatával, küllemével és ízvilágával kapcsolatosan, amit 1-től 5 -ig terjedő skálán (1: egyáltalán nem ért egyet, 5: teljes mértékben egyetért, o: nem tudja eldönteni) kellett pontozniuk a válaszolóknak.

A 3. táblázat adatai alapján megállapíthatjuk, hogy a füstölt barramundi elnyerte a megkérdezettek tetszését, megfelelt az ízlésüknek. Az is látható, hogy a kérdést megválaszolók kis hányada bizonytalankodott csupán egyik-másik kijelentésnél (,Nem tudja eldönteni” oszlop). Ezeket az átlag számításánál nem vettük figyelembe, mert torzította volna az eredményt.

Első lépésként a termék illatával kapcsolatos benyomások értékelését kértük a megkérdezettektől. Pozitív és negatív kicsengésủ állításokat fogalmaztunk meg, és ezekre vonatkozóan kértük, hogy egyetértésük mértékét fejezzék ki a korábban ismertetett skálát alkalmazva. A válaszolók teljes mértékben egyetértettek azzal, hogy a megkóstolt haltermék illata jellegzetesen füstölt hal illatú, éppen megfelelő $(4,65)$ és egybehangzóan elutasították, hogy túlzottan füstös $(1,37)$, esetleg kellemetlen mellékillatú $(1,16)$ lenne. Valamivel nagyobb szórásértéket figyelhetünk meg az „illata túlzottan füszeres” 
állítás esetében $(1,04)$, melynek eredményeként az átlagérték 1,5 lett, azaz valamennyire nem értettek egyet a kijelentéssel a válaszadók, de teljesen nem utasították azt el.

Az első három kijelentés (illata jellegzetesen füstölt hal illatú, éppen megfelelö; illata túlzottan füstös; illata kellemetlen mellékillatú) vonatkozásában a szignifikancia-vizsgálat a foglalkozás és a korcsoportok szerinti szegmentáció során szignifikáns különbséget jelzett. A foglalkozás szerinti szegmentáció Kruskal-Wallis teszttel $\mathrm{p}=0,029, \mathrm{p}=0,0008$ és $\mathrm{p}=0,0043$ valószínúségi szint mellett mutatott szignifikáns differenciát. A páronkénti próbák segítségével megállapíthattuk, hogy mely szegmensek véleménykülönbsége bizonyult kiemelkedőnek. Az „illata jellegzetesen füstölt hal illatú, éppen megfelelő" kijelentésnél az aktív szellemi dolgozók és az egyéb státuszúak (Mann-Whitney teszt, $\mathrm{p}=0,021$ ), valamint a nyugdíjasok és egyéb státuszúak (Mann-Whitney teszt, $\mathrm{p}=0,006)$ értékelése tért el szignifikánsan. Ezzel a kijelentéssel legnagyobb mértékben a nyugdíjasok, legkevésbé az egyéb státuszúak értettek egyet. Az „illata túlzottan füstös” állításnál az aktív fizikai dolgozók és az egyéb státuszúak (Mann-Whitney teszt, $\mathrm{p}=0,004)$, az aktív szellemi dolgozók és egyéb státuszúak (Mann-Whitney teszt, $\mathrm{p}=0,0008$ ), valamint a nyugdíjas és egyéb státuszúak (Mann-Whitney teszt, $\mathrm{p}=0,0001$ ) pároknál tapasztaltunk szignifikáns véleménykülönbséget. A nyugdíjasok értettek legkevésbé egyet a kijelentéssel, és az egyéb státuszúak értékelése volt a legmagasabb. Az „illata túlzottan füszeres" kijelentésnél az aktív szellemi dolgozók és a nyugdíjasok (Mann-Whitney teszt, $\mathrm{p}=0,025$ ), valamint a nyugdíjas és egyéb státuszúak (Mann-Whitney teszt, $\mathrm{p}=0$,004) véleményeltérése mutatkozott szignifikánsnak. Ennél a kijelentésnél is a nyugdíjasok értettek legkevésbé egyet a kijelentéssel.

A korcsoportok szerinti szegmentáció Kruskal-Wallis teszttel $\mathrm{p}=0,001, \mathrm{p}=0,001$ és $\mathrm{p}=0,030$ valószínüségi szinten eredményezett szignifikáns különbséget. Az „illata jellegzetesen füstölt hal illatú, éppen megfelelo"” kijelentés a 30 év alatti és 30-50 év közötti (Mann-Whitney teszt, $\mathrm{p}=0,011$ ), valamint a 30 év alatti és 50 év feletti (Mann-Whitney teszt, $\mathrm{p}=0$,0002) korcsoportok bírálatában tért el je- lentősen. Az „illata túlzottan füstös” állításnál a 30 év alatti és 50 év feletti (Mann-Whitney teszt, $\mathrm{p}=0,0004$ ), valamint a 30-50 év közötti és 50 év feletti (Mann-Whitney teszt, $\mathrm{p}=0,002$ ) korcsoportok válaszai bizonyultak szignifikánsan eltérőnek. Ennek oka, hogy legkevésbé az 50 év fölötti korosztály képviselői érezték túlzottan füstösnek a kóstolt haltermék illatát. Az „illata túlzottan füszeres” kijelentés esetében a 30-50 év közötti és az 50 év feletti korosztályba tartozók értékelése közötti különbség volt szignifikáns (Mann-Whitney teszt, $\mathrm{p}=0,008$ ). $\mathrm{Az} 50$ év felettiek érezték legkevésbé füszeres illatúnak a kóstolt halat, míg a 30-50 év közöttiek a legnagyobb mértékben. Ez az eredmény azt bizonyítja, hogy bizonyos kor fölött talán tompulnak az érzékszervek, kevésbé érezzük erősnek az illatokat.

A kóstoltatás következő lépése a „látvány” alapján történő megítélés volt, vagyis a kóstolt termék színének, állagának minősítése. Két állítást fogalmaztunk meg ehhez kapcsolódóan: „szép, bizalomgerjesztő a hús felszíne, állaga”, valamint „színe megfelel a füstölt hallal szembeni általános elvárásoknak”. Mindkettô tekintetében a megkérdezettek teljes egyetértésüknek adtak kifejezést, előbbi 4,65, utóbbi 4,76 átlagértéket kapott. Mindkét állítás esetében kicsi volt a válaszok szórása, így szignifikáns differenciát sem tudtunk megállapítani a szegmentációk során.

Az illat és a látvány után következett az „íz” értékelése, amelyen belül egyrészt a négy alapíz (sós, édes, savanyú, keserü) esetleges dominanciáját vizsgáltuk, valamint a füszerességet és a füstösséget. Legnagyobb mértékben a sós ízt $(2,33)$, a füszerességet $(1,80)$ és a füstösséget $(1,56)$ érezték ki a válaszolók, legkevésbé az édes ízt $(1,46)$, a savanyút $(1,16)$ és a keserüt $(1,11)$.

$\mathrm{Az}$ „ízvilága leginkább sós” kijelentés korcsoportonkénti szegmentációja Kruskal-Wallis teszttel $\mathrm{p}=0,034$ hibavalószínüség mellett jelzett szignifikáns differenciát. A páronkénti próbák eredményeként azt kaptuk, hogy a 30 év alatti és az 50 év feletti (Mann-Whitney teszt, $\mathrm{p}=0,018)$, valamint a 30-50 év közötti és 50 év feletti korcsoportok (Mann-Whitney teszt, $\mathrm{p}=0,045$ ) válaszai tértek el leginkább. Hasonlóan, mint az illat értékelésénél, itt is jellemzően az 50 év felettiek érezték tompábban 
az ízeket és értékelték sokkal alacsonyabban a sósságot $(1,99)$.

$\mathrm{Az}$ „ízvilága leginkább édes” kijelentés nemek szerint (Mann-Whitney teszt, $\mathrm{p}=0,003$ ) és a halfogyasztás gyakorisága szerint (Mann-Whitney teszt, $\mathrm{p}=0,025$ ) vizsgálva is szignifikáns differenciát eredményezett. A férfiak valamivel édesebbnek (1,7) érezték a kóstolt haltermék ízét, mint a nők $(1,3)$, és az alkalmi halfogyasztók is $(1,61)$, szemben a rendszeres halevőkkel $(1,23)$.

A megkóstolt termékprototípust a megkérdezett férfiak valamivel savanyúbb ízvilágúnak érezték $(1,32)$, mint a nők $(1,05)$ (Mann-Whitney teszt, p=0,o02). Keserü ízvilágúnak pedig inkább az alkalmi halfogyasztók találták $(1,19)$, miután a rendszeres halfogyasztók közül senki nem jelölt meg 1-nél magasabb értéket (Mann-Whitney teszt, $\mathrm{p}=0,013$ ).

A füszeresség inkább a 30-50 év közötti korcsoportot képviselő válaszadók számára volt valamivel eróteljesebb $(2,1)$, legkevésbé az 50 év felettiek érezték annak $(1,47)$ (Mann-Whitney teszt, $\mathrm{p}=0,001$ ) (a korcsoport szerinti szegmentáció Kruskal-Wallis teszttel, $\mathrm{p}=0,006$ valószínúségi szinten jelzett szignifikáns differenciát).

$\mathrm{Az}$ „ízvilága erősen füstös” kijelentés korcsoportonként (Kruskal-Wallis teszt, $\mathrm{p}=\mathrm{0}, 002$ ) és a válaszadók jövedelmi helyzete szerint (Mann-Whitney teszt, $\mathrm{p}=0,038$ ) csoportosítva is szignifikáns differenciát mutatott. A korcsoportonkénti szegmentáció esetében a páronkénti próbák alapján a 30 év alatti és 50 év feletti (Mann-Whitney teszt, $\mathrm{p}=0,013)$, valamint a 30-50 év közötti és az 50 év feletti (Mann-Whitney teszt, $\mathrm{p}=0,0004$ ) válaszadói szegmensek értékelésében eredményezett jelentős eltérést. Ebben az esetben is - mint korábban - az 50 év felettiek értékelték legkevésbé füstös ízűnek a terméket $(1,27)$. A jövedelmi helyzet szerinti szegmentáció esetében a magukat átlag feletti jövedelmi helyzetűnek vallók találták valamivel füstösebb ízvilágúnak a kóstolt terméket $(1,83)$, szemben a magukat átlagos jövedelmi helyzetűnek tekintőkkel $(1,5)$.

$\mathrm{Az}$ utolsó előtti kijelentés valamivel túlmutat a puszta ízérzékelésen, itt ugyanis azt a kijelentést fogalmaztuk meg, hogy „A hal füszerezése illik a hal karakteréhez.”. Ez az állítás néhány válaszadót (8 fó) elbizonytalanított, de összességében a megkérdezettek teljes mértékben egyetértettek vele (4,76). A nemek szerinti szegmentáció ennél a kijelentésnél Mann-Whitney teszttel, $\mathrm{p}=0,002$ hibavalószínűség mellett mutatott szignifikáns differenciát. A nők 4,88, míg a férfiak 4,58 átlaggal értékelték ezt az állítást. A halfogyasztás gyakorisága alapján csoportosítva (Mann-Whitney teszt, $\mathrm{p}=0$,005) megállapítottuk, hogy a rendszeres halfogyasztók inkább egyetértettek a fenti kijelentéssel $(4,9)$, mint az alkalmi halevők $(4,66)$.

Végül „A kóstoló alapján szívesen kipróbálnám és ajánlanám másoknak is” állítással zártuk le a kóstoltatást. A 3. táblázat adatai alapján látható, hogy ennél a kijelentésnél volt a legmagasabb az átlageredmény $(4,9)$, a szórás pedig a legalacsonyabb $(0,4)$. 
A válaszadók értékelése a füstölt barramundi filé kóstolását követően (The Respondents' Assessment of Smoked Barramundi Fillet After Tasting)

\begin{tabular}{|c|c|c|c|c|c|c|c|}
\hline \multirow[b]{2}{*}{ Állítások (Statements) } & \multicolumn{7}{|c|}{ Statisztikai mutatók (Statistical Indicators) } \\
\hline & $\mathbf{N}$ & NTE & $\mathbf{\Sigma N}$ & Min. & Max. & $\begin{array}{l}\text { Átlag* } \\
\text { (Mean) }\end{array}$ & $\begin{array}{l}\text { Szórás* } \\
\text { (Standard } \\
\text { Deviation) }\end{array}$ \\
\hline $\begin{array}{l}\text { Illata jellegzetesen füstölt hal illatú, } \\
\text { éppen megfelelö (Its odour is typically } \\
\text { that of smoked fish, it is just right) }\end{array}$ & 184 & 1 & 185 & 1 & 5 & 4,67 & 0,75 \\
\hline $\begin{array}{l}\text { Illata túlzottan füstös (Its odour is too } \\
\text { smoky) }\end{array}$ & 184 & 1 & 185 & 1 & 5 & 1,37 & 0,93 \\
\hline $\begin{array}{l}\text { Illata túlzottan füszeres (Its odour is } \\
\text { too spicy) }\end{array}$ & 184 & 1 & 185 & 1 & 5 & 1,50 & 1,04 \\
\hline $\begin{array}{l}\text { Illata kellemetlen mellékillatú (nem a } \\
\text { termékre jellemző) (Its odour has an } \\
\text { unpleasant side-smell (not typical of } \\
\text { the product)) }\end{array}$ & 184 & 1 & 185 & 1 & 5 & 1,16 & 0,59 \\
\hline $\begin{array}{l}\text { Szép, bizalomgerjesztő a hús felszíne, } \\
\text { állaga (The surface and texture of the } \\
\text { meat are nice and attractive) }\end{array}$ & 185 & o & 185 & 1 & 5 & 4,65 & 0,83 \\
\hline $\begin{array}{l}\text { Színe megfelel a füstölt hallal szembeni } \\
\text { általános elvárásoknak (Its colour } \\
\text { meets the general requirements of } \\
\text { smoked fish products) }\end{array}$ & 179 & 4 & 183 & 1 & 5 & 4,76 & 0,70 \\
\hline $\begin{array}{l}\text { Ízvilága leginkább SÓS (It tastes } \\
\text { mostly } S A L T Y \text { ) }\end{array}$ & 183 & 1 & 184 & 1 & 5 & 2,33 & 1,59 \\
\hline $\begin{array}{l}\text { Ízvilága leginkább ÉDES (It tastes } \\
\text { mostly SWEET) }\end{array}$ & 185 & o & 185 & 1 & 5 & 1,46 & 1,01 \\
\hline $\begin{array}{l}\text { Ízvilága leginkább SAVANYÚ (It tastes } \\
\text { mostly SOUR) }\end{array}$ & 185 & o & 185 & 1 & 5 & 1,16 & 0,66 \\
\hline $\begin{array}{l}\text { Ízvilága leginkább KESERÜ (It tastes } \\
\text { mostly BITTER) }\end{array}$ & 185 & o & 185 & 1 & 5 & 1,11 & 0,54 \\
\hline $\begin{array}{l}\text { Ízvilága leginkább ERÖSEN } \\
\text { FƯSZERES (It is VERY SPICY) }\end{array}$ & 183 & o & 183 & 1 & 5 & 1,80 & 1,25 \\
\hline $\begin{array}{l}\text { Ízvilága leginkább ERŐSEN FÜSTÖS } \\
\text { (It is } V E R Y S M O K Y \text { ) }\end{array}$ & 185 & o & 185 & 1 & 5 & 1,56 & 1,00 \\
\hline $\begin{array}{l}\text { A hal füszerezése illik a hal } \\
\text { karakteréhez (It is spiced } \\
\text { harmoniously with the typical feature } \\
\text { of the fish) }\end{array}$ & 176 & 8 & 184 & 1 & 5 & 4,76 & 0,73 \\
\hline $\begin{array}{l}\text { A kóstoló alapján szívesen } \\
\text { kipróbálnám és ajánlanám másoknak } \\
\text { is (After the tasting, I would be glad } \\
\text { to try the product and recommend it } \\
\text { to others) }\end{array}$ & 185 & o & 185 & 1 & 5 & 4,90 & 0,44 \\
\hline
\end{tabular}




\section{KöVETKEZTETÉSEK - CONCLUSIONS}

A halfogyasztási és halvásárlási szokásokkal kapcsolatban az alábbi konklúziókat lehet öszszefoglalni:

- A piackutatásba bevont mintasokaság többsége alkalmi halfogyasztó, akik elsősorban „filés” kiszerelésben vásárolják a friss tengeri halat, mivel haltermék vásárlásakor az egyik legfontosabb motiváció, hogy az szálkamentes legyen. A kínált halfilével kapcsolatban pedig elvárják, hogy az ne legyen nyálkás/nyákos, vizes és erős halszagú.

- A felmérésben résztvevő sokaság jellemzően magasabban kvalifikált (ez a réteg vásárolt a két Auchan áruházban a halpult környékén), ezért tudatosabb élelmiszerfogyasztó, így a haltermék vásárlásakor további kiemelkedő motivációja az ízletesség és a magyarországi származás.

- A hazai fogyasztói köztudatban a fenntartható haltermelés/halászat sajnos gyakorlatilag ismeretlen fogalom - még a rendszeres halfogyasztók körében is. A felmérésünkbe bevont vásárlók egyáltalán nem ismerték az ezzel kapcsolatos tanúsítványt, szervezeteket.

A barramundi:

- Tulajdonképpen ismeretlen volt a vizsgálatba bevont megkérdezettek számára, aminek az egyik fő oka, hogy kevés ezzel kapcsolatos híradással találkoztak.

- Természetesen a halvásárlási és -fogyasztási szokásokból adódóan ezt a halfajt is elsősorban filé formájában vásárolnák a fogyasztók.

- Összességében kedvezőek voltak a hallal kapcsolatos benyomások: a barramundi szimpatikus megjelenésü, prémium kategóriás hal.

A termékfejlesztés, azaz a füstölt barramundi mint funkcionális termék kedvező fogyasztói fogadtatásra lelt:

- A kifejlesztett termék potenciális célközönsége fogyasztott már korábban füstölt halat és meg volt elégedve annak ízvilágával.
- Egyáltalán nincsenek tisztában a fogyasztók, hogy tartalmában pontosan mit takar a „funkcionális élelmiszer” kifejezés, ugyanakkor az ilyen irányú termékfejlesztést helyeselték. Legszimpatikusabbnak a szív és a szem egészségét megőrző, betegségét megelőző funkcionális élelmiszer-komponenseket nevezték meg.

- A bemutatott termékprototípust pozitívan fogadták, mind a csomagolás, mind pedig a megkóstolt termék vonatkozásában.

Összességében elmondható, hogy a termékfejlesztés iránya jó, minden szempontból kielégíti a hazai célközönség halfogyasztással kapcsolatos szokásait, elvárásait és igényeit. Tudatosítani kell a fogyasztókban a „funkcionális élelmiszer" kifejezést. Amennyiben cél a fenntartható halgazdaságot igazoló tanúsítvány (asc) megszerzése, akkor gondoskodni kell arról, hogy a fogyasztók kellóképpen informálva legyenek ennek szakmai hátteréről.

\section{5. ÖSSZEFOGLALÁS - SUMMARY}

A tanulmány a barramundi halfajból készült füstölt halfilé funkcionális élelmiszer irányába történő fejlesztésével kapcsolatos termékkóstoltatással egybekötött primer kutatás - a terjedelmi korlátoknak köszönhetően - legfontosabb eredményeit mutatja be. A kutatás célja az volt, hogy információt nyújtson a célközönség, esetünkben a hipermarketekben vásárló fogyasztók: (1) egyes halfogyasztási szokásairól, (2) a tudatos halfogyasztáshoz kapcsolódó attitüdjeikről, (3) az elmúlt időszakban a hazai piacra bevezetett barramundi halfaj ismertségéről, az azzal kapcsolatos fogyasztói benyomásokról, (4) valamint a legújabb termékfejlesztés (pozitív élelmi hatású anyagokkal (pl. vitamin komplex, tökmagolaj, ginkóbiloba-kivonat, máriatövismag-olaj stb.) dúsított füstölt barramundi fogyasztói megítéléséről. Az eredmények alapján elmondhatjuk, hogy kedvezőek voltak a barramundival kapcsolatos fogyasztói benyomások, mivel a halfajt alapvetően szimpatikus megjelenésü, prémium kategóriás halként pozícionálták. A termékfejlesztés, azaz a füstölt barramundi filé mint funkcionális élelmiszer kedvező fogyasztói fogadtatásra lelt. A 
kifejlesztett termék potenciális célközönsége fogyasztott már korábban füstölt halat és meg volt elégedve a kóstolót követően az új termék ízvilágával. Fontos hangsúlyozni, hogy a megkérdezettek egyáltalán nem voltak tisztában azzal, hogy mit takar a „funkcionális élelmiszer” kifejezés, ugyanakkor az ilyen irányú termékfejlesztést helyeselték. Legszimpatikusabbnak a szív és a szem egészségét megőrző, betegségét megelőző funkcionális élelmiszer-komponenseket nevezték meg. A kutatás alapján elmondható, hogy a termékfejlesztés iránya jó, minden szempontból kielégíti a hazai célközönség halfogyasztással kapcsolatos szokásait, elvárásait és igényeit.

\section{IRODALOMJEGYZÉK - REFERENCES}

Barna M.: A táplálkozás és az egészség szempontjai az élelmiszeripar fejlődésében. $\mathrm{Az}$ élelmiszeripar jövője. ÉFOSZ, Élelmiszertechnológiai Platform, Földmúvelési és Vidékfejlesztési Minisztérium, Budapest, 2007. jún. 20.

Careche, M.: Functional Seafood Products: Some Outcomes from the SEAFOODplus Project. In: Functional Foods: Some Pointers for Success. E-publication, UCD Institute of Food and Health, Dublin, 1. dec. 2010.

Európai Bizottság Tengerügyi és Halászati Főigazgatóság: Facts and Figures on the Common Fisheries Policy. 2016. URL: http://ec.europa.eu/fisheries/ documentation/publications/pcp_en.pdf (Letöltés dátuma: 2016. máj. 02.)

FAO: Fishery and Aquaculture Statistics. In: The Food and Agriculture Organization (FAO) yearbook. 2012. Rome

FAO: Fishery and Aquaculture Statistics. In: The Food and Agriculture Organization (FAO) yearbook. 2014. Rome

KSH: A haltermelés és -fogyasztás alakulása a világon és Magyarországon. In: Statisztikai Tükör. 2013. 7 (84)

MAHAL: Jelentés a Szövetség múködésének 2014. évi eredményeiről. Magyar Haltermelők és Halászati Vízterülethasznosítók Szövetsége, 2015. URL: http://docplayer.hu/9978931-Magyar- haltermelok-es-halaszati-vizterulethasznositok-szovetsege-budapest-xiballagi-mor-utca-8-fsz-2.html (Letöltés dátuma: 2016. máj. 05.)

Mendis, S. - Puska, P. - Norrving, B.: Global Atlas on Cardiovascular Disease Prevention and Control. World Health Organization, Geneva, 2011. URL: http://whqlibdoc.who.int/ publications/2011/9789241564373_eng. pdf (letöltés ideje: 2016. ápr. 10.)

Menrad, K.: Market and Marketing of Functional Food in Europe. In: Journal of Food Engineering. 2003. 56 181-188.

Mollet, B. - Rowland, I.: Functional Foods: At the Frontier between Food and Pharma. Current Opinion in Biotechnology. 2002. 13 (1) 483-485.

Panyor Á.: A különleges élelmiszerek piacnövelési lehetőségei megkérdezések tükrében. Doktori értekezés, Budapest, 2007.

Piskóti I. - Nagy Sz. - Kovács A. T.: Fogyasztói magatartás a funkcionális élelmiszerek piacán. In: Marketing Kaleidoszkóp. Miskolc, 2006. 117-127.

Puska, P. - Waxman, A. - Porter, D.: The Global Strategy on Diet, Physical Activity and Health. World Health Organization, Geneva, 2003.

Szakály Z.: Korszerü állati eredetű alapélelmiszerek piacképességének vizsgálata. Kandidátusi értekezés, PATE, Állattenyésztési Kar, Kaposvár, 1994.

Szakály Z. - Schäffer B.: A stratégiai termékinnováció fóbb területei az élelmiszer-gazdaságban. II. Táplálkozásmarketing Konferencia - Innováció és marketing az élelmiszeriparban: funkcionális élelmiszerek, Kaposvár, 2006. máj. 18.

Young, Y.: Functional oods and the European Consumer. In: Functional Foods. II. Claims and Evidence. (Szerk.: Buttriss, J. - Saltmarsh, M.), London, UK: The Royal Society of Chemistry, 2000. 25-34. 